\title{
ВИХОВАННЯ ТОЛЕРАНТНОСТІ В УЧНІВ ШКІЛ ФРАНЦІЇ У КОНТЕКСТІ МОРАЛЬНОЇ ТА ГРОМАДЯНСЬКОЇ ОСВІТИ
}

Толерантність є однією з важливих иінностей франиузької системи освіти, яка виховується у школі. Передавати иінності є місією школи наряду з передачею знань та вмінь. Необхідність виховання толерантності в учнів франиузьких шкіл зумовлена актуальною політичною та сочіальноекономічною ситуацією у Франції. Зростання проявів нетерпимості, насильства, ксенофобії, расизму у суспільстві спонукало державу до активних дій у сфері державної освіти, зокрема, до введення такого обов'язкового предмету, як моральна та громадянська освіта. Метою статті є висвітлення досвіду виховання толерантності в учнів середніх шкіл Франиї у контексті шкільного предмету «моральна та громадянська освіта». У статті розглянуто проиес виховання толерантності через призму морального та громадянського виховання. За допомогою аналізу змісту навчальної програми, а також таких методів, як синтез, узагальнення, систематизація, структурний метод, виокремлено основні підходи до виховання толерантності, відповідні принципи морального та громадянського виховання, а також компоненти, за допомогою яких здійснюється прищеплення толерантності учням шкіл Франщії.

Виховання толерантності в учнів середніх шкіл Франції є системним, постійним процесом, організованим на державному рівні. Воно реалізується, зокрема, через викладання обов'язкового предмету «моральна і громадянська освіта», щуо охоплює всіх учнів від початкової до старшої школи. Виховання толерантності здійснюється згідно принципів морального і громадянського виховання (принципу автономії, принципу дисципліни, принципу співіснування, принципу спільності) та трунтується на цінностях Франиузької республіки.

Згідно принципів морального та громадянського виховання виявлено підходи до виховання толерантності: чутливий, нормативний, когнітивний та практичний. Кожному з цих підходів відповідають певні компоненти, такі як чутливість, судження, закон та правило, обов'язок та відповідальність. Вони знаходять своє втілення на практииі під час проведення занять із предмету «моральна та громадянська освіта».

Ключові слова: виховання, толерантність, школа, Франція, моральна та громадянська освіта. 
Lysenko N. H. Education of tolerance in the pupils of France schools in the context of moral and civil education. Tolerance is one of the important values of the French education system that is brought up at school. Transferring values is the mission of the school along with the transfer of knowledge and skills. The need for fostering tolerance in French school students is driven by the current political and socio-economic situation in France. The rise in manifestations of intolerance, violence, xenophobia, racism in society has led the state to take active steps in public education, in particular, to introduce such a compulsory subject as moral and civic education. The purpose of the article is to highlight the experience of fostering tolerance in French secondary schools in the context of the school subject of "moral and civic education". The process of education of tolerance through the prism of moral and civic education is considered in the article. By analyzing the content of the curriculum, as well as methods such as synthesis, generalization, systematization, structural method, the basic approaches to the education of tolerance, the corresponding principles of moral and civic education, as well as the components by which the introduction of tolerance to the students of French schools are highlighted.

Educating tolerance in French secondary schools is a systematic, ongoing process organized at the state level. It is implemented, inter alia, through the teaching of the compulsory subject of "moral and civic education", which covers all students from elementary to high school. Education of tolerance is carried out in accordance with the principles of moral and civic education (principle of autonomy, principle of discipline, principle of coexistence, principle of community) and is based on the values of the French Republic.

According to the principles of moral and civic education, the following approaches to the cultivation of tolerance have been identified: sensitive, normative, cognitive and practical. Each of these approaches has different components, such as sensitivity, judgment, law and rule, obligation and responsibility. They find their practice in the subject of "moral and civic education".

Keywords: education, tolerance, school, France, moral and civic education

Вступ. Виховання толерантності в учнів є одним із провідних завдань сучасної системи освіти Франції, що зумовлено політичною та соціальноюекономічною ситуацією, що склалася в країні, починаючи 3 другої половини XX століття, а саме: збільшення потоку іммігрантів, що прибувають із країн 3 іншою релігією, культурою та цінностями, етнічна та культурна різноманітність населення країни, загострення соціально-економічних проблем у суспільстві, проблема дискримінації певних категорій населення, хвиля насильства, ксенофобії та тероризму.

Визначення толерантності знаходимо в Декларації принципів толерантності ЮНЕСКО від 16 листопада 1995 р. Зазначена категорія визначається, як: повага, прийняття i правильне розуміння багатого 
різноманіття культур оточуючого світу, форм самовираження і способів проявів людської індивідуальності (UNESCO, 1995, November 16).

Французькі педагоги та науковці вважають толерантність синонімом таких понять як «розуміння», «доброзичливість», «милосердя», «поблажливість», «помірність», «ліберальність», «неупередженість» (Détrie $\&$ Lauriol, 2014). Аналіз наукових праць французьких педагогів (Ж. Гійо, Д. Коллен, Ж. Ватерло, Г. Лере, Ж. Амуд та ін.) доводить, що толерантність уважається цінністю, яка має виховуватися у школі. Говорячи про необхідність виховання толерантності у школярів, Д. Коллен наполягає на місії школи щодо морального виховання учнів, прищеплення їм основних цінностей суспільства. На думку французького педагога, необхідно розвивати у дітей здатність дотримуватися цінностей, поважати їх. Серед цінностей, які варті уваги, автор називає, насамперед, істину та об'єктивність, а також вірність, честь, повагу та толерантність. Прищеплення цінностей є результатом регулярних «вправ», виконання яких є складовою навчання у школі (Collin, 2005).

Одним із головних чинників формування толерантності у дітей шкільного віку французькі вчені вважають розвиток критичного мислення. За їх переконанням, «тільки звичка інтелектуальної жорсткості, пошуку об'єктивності та критичного мислення може ефективно сприяти формуванню вільних громадян, а не підпорядкування сумнівним цінностям та ідеологічне вербування» (Collin, 2005).

Школа стикається з безліччю культур, приймає учнів з різноманітною самоідентифікацією. Серед великої кількості тем, які обговорюють учителі, щоб спонукати учнів французьких шкіл до толерантності, найчастіше згадуються теми, пов'язані з соціальними відмінностями та вибором релігії. Фізичні та культурні відмінності, труднощі у навчанні в окремих учнів, інвалідність, гомофобія, гендерна рівність, свобода думок, повага до іншого, суперечки між учнями, імміграція, актуальні події також належать до питань обговорення між учителем і учнями, і це обговорення зосереджене на важливості толерантності як цінності та поведінки, яку вона зумовлює у тій чи іншій ситуації (Hammoud, 2015).

Дослідження української вченої О. Матієнко щодо виховання толерантності у старшокласників середніх загальноосвітніх ліцеїв Франції виявило, що зміст багатьох предметів надає учням різнобічні знання та спрямований на всебічну соціалізацію дитини, що $є$ необхідною умовою виховання толерантності. Серед них особливе місце мають, наприклад, французька мова і література, іноземні мови, філософія, економічні та соціальні науки, естетичне та фізичне виховання. Але найбільший потенціал 
щодо виховання толерантності характерний для таких дисциплін, як історія, географія та громадянознавство або громадянська освіта (Matienko, 2006).

Мета та завдання. Метою статті є висвітлення досвіду виховання толерантності в учнів середніх шкіл Франції у контексті шкільного предмету «моральна та громадянська освіта».

Відповідно до мети визначено такі завдання:

- схарактеризувати принципи виховання толерантності у школярів Франції;

- проаналізувати зміст навчальної програми 3 моральної та громадянської освіти;

- виявити компоненти моральної та громадянської освіти, що спрямовані на виховання толерантності;

- з'ясувати види практичної діяльності, через які реалізується виховання

толерантності у Франції.

Методи дослідження. Згідно з поставленими метою та завданнями було використано такі методи дослідження, як: аналіз філософської, психолого-педагогічної літератури з теми дослідження, синтез, узагальнення, систематизація, структурний метод, що дає змогу розглядати виховання толерантності як систему, виділяючи його складові.

Результати. Сучасна система шкільної освіти Франції грунтується на певних цінностях, що відповідають цінностям Французької республіки, а саме: свобода, рівність, братерство, світськість, солідарність, дух справедливості, повага та відсутність будь-яких форм дискримінації. При цьому пояснюється, що «цінності Республіки пов'язані, перш за все, з гуманістичними цінностями, які визначають іiі цивілізаційний характер, такими, як етика істини, вимоги розуму, суспільне благо, дух закону, толерантність та прагнення до миру» (Ministère de l'éducation nationale et de la jeunesse, 2015, April 23). Виховання громадянськості спирається на цінності Французької республіки, закладені ще Декларацією прав людини i громадянина, прийнятою у 1789 році, де викладені філософські та правові засади толерантності у широкому розумінні цього терміну. Цінності Республіки відображено у іiі девізі: «Свобода, Рівність, Братерство». Розвиток французької демократії зумовив появу нових цінностей, таких, як, наприклад, світськість (або «секуляризм») (фр. laïcité) - відокремлення церкви від держави, що виключає церкву з політичної та адміністративної влади, зокрема, зі сфери організації державної освіти, що було закріплено законом від 1905 р. (Bauberot, 2004). 
Державні освітні програми шкіл Франції, окрім спеціальних дисциплін, включають також «загальне ядро знань, умінь і культури» (фр. Socle commun de connaissances, de compétences et de culture) - сукупність знань, навичок, цінностей і поведінки, необхідних для успішного навчання та життя учня як особистості і як майбутнього громадянина, від 6 до 16 років. Згідно 3 постановою Міністерства національної освіти № 2015-372 від 31.03.2015 р. загальне ядро «забезпечує відкриту загальну освіту, спільну для всіх i засновану на цінностях, що дозволяють людям жити в толерантному, вільному суспільстві» (Ministère de l'éducation nationale et de la jeunesse, 2015, April 23).

Виховання толерантності, на думку французьких педагогів, $\epsilon$ невід'ємною складовою громадянського виховання. Ф. Одіж'є вважає, що останнє «Грунтується на необхідності передачі знань щодо правил суспільного життя, функціонування установ, а також цінностей, які відповідають очікуваній поведінці громадянина у суспільстві» (Audigier, 1991). Слід відзначити, що у Франції потягом ХХ століття простежується певна еволюція від виховання моральності до громадянської освіти (instruction civique), а згодом до громадянського виховання (éducation civique). 3 90-х років XX століття у Франції вживається термін «громадянознавство» (éducation à la citoyenneté) (Mc Andrew, Tessier \& Bourgeault, 1997).

Внаслідок терористичних атак, здійснених у Франції у січні 2015 року, Міністерство освіти оголосило «мобілізацію школи щодо цінностей Республіки», яка охоплює весь навчальний шлях учня від дошкільної освіти до випускного класу ліцею. Починаючи з вересня того ж року, у французьких школах викладається обов'язковий предмет «моральна та громадянська освіта» (фр. Enseignement moral et civique).

Метою моральної та громадянської освіти у Франції є сприяння розвитку здатності жити разом у нероздільній, світській, демократичній та соціальній державі (Ministère de l'éducation nationale, de l'enseignement sepérieur et de la recherche, 2015, June 25). У новій програмі морального та громадянського виховання виокремлено чотири основні його принципи:

1) мислити та діяти самому та разом з іншими, вміти аргументувати свою позицію та вибір (принцип автономіі);

2) розуміти законність норм і правил, що регулюють індивідуальну та колективну поведінку, поважати їх і діяти відповідно до них (принцип дисципліни);

3) визнавати плюралізм думок, переконань, вірувань та способів життя (принцип співіснування свобод); 
4) будувати соціальні і політичні зв'язки (принцип спільності громадян) (Ministère de l'éducation nationale, de l'enseignement sepérieur et de la recherche, 2015, June 25).

Аналізуючи наведені принципи, можна дійти висновку, що моральна та громадянська освіта спрямовані великою мірою на виховання толерантності.

Відповідно до цих принципів, виховання толерантності на уроках моральної та громадянської освіти має чотири підходи, тісно пов'язані між собою, а саме:

- чутливий підхід - виховання чутливості має на меті краще розпізнавати та виявляти свої почуття та емоції, висловлювати та обговорити їх, а також краще розуміти почуття інших;

- нормативний підхід - навчання законів та правил з метою показати, як у демократичному суспільстві спільні цінності втілюються у загальних правилах життя;

- когнітивний підхід - формування морального судження, яке надає можливість зрозуміти та обговорити моральний вибір, з яким стикається кожен у своєму житті. Це результат виховання та навчання, що вимагає від учнів сприймати точку зору інших людей, різні форми моральних міркувань, ставить їх у певні ситуації, що вимагають аргументації, розмірковування, обговорювання. Розвиток морального судження апелює до аналізу, обговорення, обміну, протистояння точок зору в проблемних ситуаціях. При цьому особлива увага приділяється мовленнєвій компетенції, здатності висловлювати свої думки усно та письмово;

- практичний підхід - формування людини та громадянина, що передбачає практичне впровадження навчання у рамках школи та загалом у колективне життя, що заохочує до співпраці, відповідальності перед іншими.

У програмі з предмету «моральна та громадянська освіта» для учнів французького колежу (3-й та 4-й цикли навчання за французькою системою шкільної освіти) ці підходи втілюються у відповідних компонентах виховання толерантності: чутливість (табл. 1), закон і правила (табл. 2), судження (табл. 3), обов'язок та відповідальність (табл. 4).

\section{Чутливість («я та інші люди»)}

Таблиия 1.

\begin{tabular}{|l|l|l|}
\hline \multicolumn{1}{|c|}{ Мета навчання } & \multicolumn{1}{|c|}{ Об’єкт навчання } & \multicolumn{1}{|c|}{$\begin{array}{c}\text { Приклади практичних } \\
\text { занять у класі }\end{array}$} \\
\hline $\begin{array}{l}\text { 1. Визначати та } \\
\text { висловлювати свої емоції та } \\
\text { почуття і керувати ними }\end{array}$ & & \\
\hline 1.1. Ділитися почуттями та & $\begin{array}{l}\text { - Різноманітність } \\
\text { вираження почуттів та }\end{array}$ & $\begin{array}{l}\text { - Театральна вистава, } \\
\text { пантоміма }\end{array}$ \\
\hline
\end{tabular}




\begin{tabular}{|c|c|c|}
\hline $\begin{array}{l}\text { керувати емоціями в } \\
\text { різноманітних ситуаціях та } \\
\text { щодо різноманітних } \\
\text { об’єктів: літературні } \\
\text { тексти, твори мистецтва, } \\
\text { актуальні події, дискусії } \\
\text { про життя класу }\end{array}$ & $\begin{array}{l}\text { емоцій у різних творах } \\
\text { (текстах, музичних творах, } \\
\text { пластичні мистецтва тощо) } \\
\text { - Оволодіння правилами } \\
\text { спілкування. }\end{array}$ & \multirow{7}{*}{$\begin{array}{l}\text { - Рольові ігри. } \\
\text { - Мовленнєва діяльність: } \\
\text { мова ситуацій, мова } \\
\text { спогадів. } \\
\text { - Мови мистецтва: } \\
\text { вираження почуттів та } \\
\text { емоцій у літературі та } \\
\text { мистецтві } \\
\text { - Повага до тіла між } \\
\text { дівчатами та хлопцями на } \\
\text { уроках фізичного } \\
\text { виховання та в усіх видах } \\
\text { шкільної діяльності, } \\
\text { пов’язаних з емоційним та } \\
\text { сексуальним вихованням. } \\
\text { - Механізми домагань та їх } \\
\text { наслідки. }\end{array}$} \\
\hline $\begin{array}{l}\text { 1.2. Мобілізувати } \\
\text { словниковий запас для } \\
\text { висловлювання емоцій та } \\
\text { почуттів }\end{array}$ & $\begin{array}{l}\text { - Знання та структурування } \\
\text { словникового запасу } \\
\text { почуттів та емоцій }\end{array}$ & \\
\hline $\begin{array}{l}\text { 2. Шанувати себе і вміти } \\
\text { слухати і співпереживати }\end{array}$ & & \\
\hline $\begin{array}{l}\text { 2.1. Поважати інших та } \\
\text { приймати відмінності }\end{array}$ & $\begin{array}{l}\text { - Повага до інших у їх } \\
\text { різноманітності: посягання } \\
\text { на особистість іншої } \\
\text { людини (расизм, } \\
\text { антисемітизм, сексизм, } \\
\text { ксенофобія, гомофобія, } \\
\text { домагання тощо). } \\
\text { - Повага до відмінностей, } \\
\text { толерантність. } \\
\text { - Повага до різноманітності } \\
\text { вірувань та переконань. } \\
\text { - Допомога іншим }\end{array}$ & \\
\hline $\begin{array}{l}\text { 2.2. Виявляти повагу до } \\
\text { інших у своїх } \\
\text { висловлюваннях та } \\
\text { ставленні }\end{array}$ & $\begin{array}{l}\text { - уважне ставлення до } \\
\text { мови: турбота про інших у } \\
\text { мові, зокрема, ввічливість; } \\
\text { - турбота про тіло та про } \\
\text { навколишнє середовище; } \\
\text { - турбота про особисті та } \\
\text { колективні блага; } \\
\text { - недоторканість людської } \\
\text { особистості. }\end{array}$ & \\
\hline $\begin{array}{l}\text { 3. Відчувати себе членом } \\
\text { громади }\end{array}$ & & \\
\hline $\begin{array}{l}\text { 3.1. Розуміти сенс символів } \\
\text { Республіки } \\
\text { 3.2. Співпрацювати }\end{array}$ & $\begin{array}{l}\text { - Цінності та символи } \\
\text { Франції та Європейської } \\
\text { спільноти. } \\
\text { - Вміння працювати, } \\
\text { дотримуючись правил } \\
\text { співпраці. }\end{array}$ & \\
\hline
\end{tabular}


Закон і правило (принципи співіснування з іншими людьми)

\begin{tabular}{|c|c|c|}
\hline Мета навчання & Об'скт навчання & $\begin{array}{c}\text { Приклади практичних } \\
\text { занять у класі }\end{array}$ \\
\hline $\begin{array}{l}\text { 1. Розуміти причини } \\
\text { дотримання правил та } \\
\text { законів в демократичному } \\
\text { суспільстві. }\end{array}$ & & \\
\hline $\begin{array}{l}\text { 1.1.Розуміти поняття прав } \\
\text { та обов'язків, приймати та } \\
\text { застосовувати їх }\end{array}$ & $\begin{array}{l}\text { - Права та обов’язки: } \\
\text { людини, дитини, учня, } \\
\text { громадянина. } \\
\text { - Лексика норми і закону } \\
\text { (право, обов’язок, правило, } \\
\text { регулювання, закон). } \\
\text { - Різні контексти } \\
\text { дотримання правил, } \\
\text { розпорядку; покарання. }\end{array}$ & \multirow[t]{5}{*}{$\begin{array}{l}\text { Фізичне виховання: ігри та } \\
\text { командні види спорту. } \\
\text { - Студентські ради, } \\
\text { демократичні дебати. } \\
\text { - Визначення та } \\
\text { обговорення у класі правил } \\
\text { дебатів чи правил } \\
\text { діяльності учнівської ради. } \\
\text { - Інвалідність: } \\
\text { філософська дискусія. }\end{array}$} \\
\hline $\begin{array}{l}\text { 1.2.Поважати інших, } \\
\text { зокрема дотримуватись } \\
\text { принципу рівності жінок та } \\
\text { чоловіків }\end{array}$ & $\begin{array}{l}\text { Рівність між дівчатами та } \\
\text { хлопцями. } \\
\text { - Змішане навчання у } \\
\text { школі. } \\
\text { - Рівні права та поняття } \\
\text { дискримінації. }\end{array}$ & \\
\hline $\begin{array}{l}\text { 2. Розуміти принципи та } \\
\text { цінності Французької } \\
\text { республіки та } \\
\text { демократичних суспільств. }\end{array}$ & & \\
\hline $\begin{array}{l}\text { 2.1.Визнавати принципи та } \\
\text { цінності Республіки та } \\
\text { Свропейського Союзу }\end{array}$ & $\begin{array}{l}\text { - Цінності: свобода, } \\
\text { рівність, світськість. }\end{array}$ & \\
\hline $\begin{array}{l}\text { 2.2. Знати основні риси } \\
\text { Французької республіки }\end{array}$ & $\begin{array}{l}\text { - Основи законодавства та } \\
\text { основні декларації прав. } \\
\text { - Поняття національного та } \\
\text { європейського } \\
\text { громадянства. }\end{array}$ & \\
\hline
\end{tabular}




\section{Судження («мислити самому та разом з іншими»)}

\begin{tabular}{|c|c|c|}
\hline Мета навчання & Об'скт навчання & $\begin{array}{c}\text { Приклади практичних } \\
\text { занять у класі }\end{array}$ \\
\hline $\begin{array}{l}\text { 1. Розвивати навички } \\
\text { критичного мислення: } \\
\text { шукати критерії } \\
\text { обгрунтованості моральних } \\
\text { суджень; порівнюючи своє } \\
\text { судження з рішеннями } \\
\text { інших у добре } \\
\text { аргументованій дискусії }\end{array}$ & & \\
\hline $\begin{array}{l}\text { 1.1. Брати участь у дискусії } \\
\text { чи діалозі: говорити з } \\
\text { іншими, слухати інших, } \\
\text { вчитися формулювати та } \\
\text { обгрунтовувати власну } \\
\text { точку зору. }\end{array}$ & $\begin{array}{l}\text { - Вибір, його } \\
\text { обгрунтування. } \\
\text { - Знання та розпізнавання } \\
\text { різних видів } \\
\text { висловлювання (розповідь, } \\
\text { звіт, свідчення). } \\
\text { - Правила групового } \\
\text { обговорення (вміння } \\
\text { слухати, повага точки зору } \\
\text { інших, пошук згоди тощо). } \\
\text { - Підхід до аргументації. } \\
\text { - Аргументована дискусія. } \\
\text { - Основи демократичних } \\
\text { дебатів. } \\
\text { - Критерії морального } \\
\text { судження: добро і зло, } \\
\text { справедливість та } \\
\text { несправедливість. }\end{array}$ & $\begin{array}{l}\text { - Вправи на критичне } \\
\text { судження: спираючись на } \\
\text { факти з життя класу, } \\
\text { школи та поза школою для } \\
\text { боротьби з упередженнями } \\
\text { (расизм, сексизм, } \\
\text { гомофобія тощо). } \\
\text { - Підхід до поняття } \\
\text { "стереотип" із ситуацій з } \\
\text { життя класу або уявних } \\
\text { ситуацій, взятих із } \\
\text { оповідань, казок чи дитячої } \\
\text { літератури. } \\
\text { - Організація керованих } \\
\text { дебатів із цих ситуацій. }\end{array}$ \\
\hline $\begin{array}{l}\text { 1.2. Бачити нюанси власної } \\
\text { позиції відносно точки зору } \\
\text { інших. }\end{array}$ & $\begin{array}{l}\text { Упередження та стереотипи } \\
\text { (расизм, антисемітизм, } \\
\text { сексизм, гомофобія). }\end{array}$ & - Медіаосвіта. \\
\hline $\begin{array}{l}\text { 1.3. Розуміти, що принцип } \\
\text { світськості дає кожному } \\
\text { рівне право вільно } \\
\text { висловлювати власні } \\
\text { судження та вимагає поваги } \\
\text { цього права в інших. }\end{array}$ & $\begin{array}{l}\text { - Світськість як свобода } \\
\text { думати, вірити чи не } \\
\text { вірити. } \\
\text { - Відмінність між } \\
\text { переконаннями та думками. }\end{array}$ & $\begin{array}{l}\text { - Різноманітність поглядів } \\
\text { на дитинство у просторі та } \\
\text { часі. }\end{array}$ \\
\hline $\begin{array}{l}\text { 1.4. Усвідомлювати } \\
\text { питання використання } \\
\text { інформаційних технологій } \\
\text { та Інтернету та мати } \\
\text { критичне ставлення до } \\
\text { отриманої інформації }\end{array}$ & $\begin{array}{l}\text { Критичне судження: } \\
\text { обробка інформації та } \\
\text { медіаграмотність. }\end{array}$ & \multirow{2}{*}{$\begin{array}{l}\text { - Аналіз фактів, } \\
\text { протистояння ідей через } \\
\text { підхід до вирішення } \\
\text { проблем та через процес } \\
\text { дослідження (наприклад, у } \\
\text { науках, художній освіті та } \\
\text { вихованні). }\end{array}$} \\
\hline $\begin{array}{l}\text { 2. Розрізняти власні } \\
\text { інтереси від спільних } \\
\text { інтересів. }\end{array}$ & & \\
\hline
\end{tabular}




\begin{tabular}{|c|c|c|}
\hline $\begin{array}{l}\text { 2.1. Відрізняти особистий } \\
\text { інтерес від колективного } \\
\text { інтересу. }\end{array}$ & $\begin{array}{l}\text { - Поняття загального блага } \\
\text { в класі, школі та } \\
\text { суспільстві. } \\
\text { - Особисті та колективні } \\
\text { цінності. } \\
\text { - Цінності та інститути: } \\
\text { девіз Республіки (Свобода, } \\
\text { Рівність, Братерство) } \\
\text { - Основні свободи. } \\
\text { - Світськість. } \\
\text { - Цінності Європейського } \\
\text { Союзу. }\end{array}$ & $\begin{array}{l}\text { - Практика аргументації та } \\
\text { аргументованих дебатів: } \\
\text { оволодіння мовними } \\
\text { засобами, лексичним } \\
\text { запасом. } \\
\text { - Вправи на уточнення } \\
\text { цінностей з точки зору } \\
\text { загальних та власних } \\
\text { інтересів. } \\
\text { - Роздуми про загальні } \\
\text { інтереси та особисті } \\
\text { інтереси на основі } \\
\text { оповідань, літературних } \\
\text { персонажів, історії або } \\
\text { міфології. } \\
\text { - Місце та роль окремих } \\
\text { особистостей, чоловіків чи } \\
\text { жінок в історії. }\end{array}$ \\
\hline
\end{tabular}

Таблиия 4

Обов'язок та відповідальність

(діяти індивідуально та разом з іншими)

\begin{tabular}{|c|c|c|}
\hline Мета навчання & Об'скт навчання & $\begin{array}{c}\text { Приклади практичних } \\
\text { занять у класі }\end{array}$ \\
\hline $\begin{array}{l}\text { 1. Залучатися до } \\
\text { колективного життя, брати } \\
\text { на себе обов’язок та } \\
\text { відповідальність. }\end{array}$ & & \\
\hline $\begin{array}{l}\text { 1.1.Залучатися до реалізації } \\
\text { колективного проекту (у } \\
\text { класі, школі, громаді, } \\
\text { державі). }\end{array}$ & $\begin{array}{l}\text { - Моральний обов’язок } \\
\text { (довіра, обіцянка, вірність, } \\
\text { взаємодопомога, } \\
\text { солідарність). } \\
\text { - Допомога іншим: уміння } \\
\text { надати першу допомогу. }\end{array}$ & \multirow{3}{*}{$\begin{array}{l}\text { - Дебати про роль довіри та } \\
\text { дотримання своїх } \\
\text { зобов’язань у житті. } \\
\text { - Принципи } \\
\text { демократичного } \\
\text { голосування в учнівських } \\
\text { радах. } \\
\text { - Обов’язок: привернути } \\
\text { увагу учнів до великих } \\
\text { постатей, (чоловіків та } \\
\text { жінок) (наукових, } \\
\text { політичних, гуманітарних } \\
\text { діячів). } \\
\text { - Вивчення преамбули }\end{array}$} \\
\hline $\begin{array}{l}\text { 1.2.Вміти пояснити свій } \\
\text { вибір та свої дії }\end{array}$ & $\begin{array}{l}\text { - Відповідальність } \\
\text { особистості та громадянина } \\
\text { у сфері навколишнього } \\
\text { середовища, здоров’я. }\end{array}$ & \\
\hline $\begin{array}{l}\text { 2. Брати на себе } \\
\text { відповідальність за } \\
\text { організацію життя громади, } \\
\text { довкілля та розвивати }\end{array}$ & & \\
\hline
\end{tabular}




\begin{tabular}{|l|l|l|}
\hline $\begin{array}{l}\text { громадянську, соціальну та } \\
\text { екологічну обізнаність. }\end{array}$ & Конституції Франції. \\
\cline { 1 - 2 } $\begin{array}{l}\text { 2.1. Вміти брати участь та } \\
\text { знайти своє місце у } \\
\text { колективі. }\end{array}$ & $\begin{array}{l}\text { - Демократична участь. } \\
\text { - Голосування. }\end{array}$ & $\begin{array}{l}\text { - Вивчення ролі асоціацій } \\
\text { та об'єднань. }\end{array}$ \\
\cline { 1 - 2 } $\begin{array}{l}\text { 2.2. Пояснювати своїми } \\
\text { словами поняття братерства } \\
\text { та солідарності. }\end{array}$ & $\begin{array}{l}\text { - Індивідуальна та } \\
\text { колективна солідарність. } \\
\text { - Братерство у девізі } \\
\text { Французької республіки. }\end{array}$ & \\
\hline
\end{tabular}

Обговорення. Проведене дослідження дозволяє стверджувати, що на відміну від інших країн світу, у французькій середній школі предмет «моральна та громадянська освіта» викладається, як правило, вчителем історії та географії. У колежі такий урок зазвичай має форму лекції, де вчитель розповідає про правила внутрішнього розпорядку, права та обов'язки учнів, різноманітні установи тощо. У ліцеї предмет здебільшого присвячений дискусії (обговорення новин, питань моралі чи життя класу), де використовуються матеріали преси, педагогічні проекти (екскурсії, благодійна допомога тощо), документальні дослідження та презентації.

Висновки. Виховання толерантності в учнів середніх шкіл Франції $\epsilon$ системним, постійним процесом, організованим на державному рівні. Воно реалізується, зокрема, через викладання обов'язкового предмету «моральна і громадянська освіта», що охоплює всіх учнів від початкової до старшої школи. Виховання толерантності здійснюється згідно принципів морального і громадянського виховання (принципу автономії, принципу дисципліни, принципу співіснування, принципу спільності) та грунтується на цінностях Французької республіки.

Аналіз змісту програми морального та громадянського виховання виявив, що виховання толерантності має декілька підходів, кожному з яких відповідають певні компоненти, такі як: чутливість, судження, закон та правило, обов'язок та відповідальність. Кожен із зазначених підходів знаходить своє втілення на практиці під час занять із предмету «моральна та громадянська освіта».

\section{ЛІТЕРАТУРА:}

Боберо Ж. Світськість: французька винятковість чи універсальна цінність? Дух і Літера. 2004. №13-14. C. 227-235.

Декларация принципов терпимости, принятая резолюцией 5.61 Генеральной конференции $\begin{array}{llllll}\text { ЮНЕСКО от } 16 & \text { ноября } 1995 & \text { года. URL: }\end{array}$ https://unesdoc.unesco.org/ark:/48223/pf0000101803_rus.page=94 (дата звернення: 23.03.2019).

Матієнко О.С. Виховання толерантності у старшокласників середніх загальноосвітніх ліцеїв Франції : автореф. дис. ... канд. пед. наук. Київ, 2006. 17 с. 
Audigier F. Enseigner la société, transmettre des valeurs: la formation civique et l'éducation aux droits de l'homme : une mission ancienne, des problèmes permanents, un projet toujours actuel. Revue française de pédagogie. 1991. № 94. C. 37-48.

Collin D. Valeurs et idéologies. URL: http://denis-collin.viabloga.com/news/valeurs-etideologies (дата звернення: 01.07.2019).

Détrie C., Lauriol C. L'idéologie des Lumières. Dire la tolérance. UNESCO, 2014. C. 49-53.

Hammoud G. Éducation à la tolérance. Empan. 2015. № 98. C. 122-125.

Mc Andrew M., Tessier C., Bourgeault G. L'éducation à la citoyenneté en milieu scolaire au Canada, aux Etats-Unis et en France: des orientations aux réalisations. Révue francaise de pédagogie. 1997. vol. 121. C. 57-77.

Programme d'enseignement moral et civique. Bulletin officiel spécial $n^{\circ} 6$ du 25 juin 2015 . URL: http://cache.media.education.gouv.fr/file/MEN_SPE_6/66/2/2015_BO_SPE_6pdf_478662.pdf (дата звернення: 10.09.2019).

Socle commun de connaissances, de compétences et de culture. Bulletin officiel $\mathrm{n}^{\circ} 17$ du 23 avril 2015.

URL: https://www.education.gouv.fr/pid25535/bulletin_officiel.html?cid_bo=87834 (дата звернення: 31.08.2019).

\section{REFERENCES:}

Bauberot, J. (2004). Svitskist: frantsuzka vyniatkovist chy universalna tsinnist? [Secularity: French exclusiveness or universal value?]. Dukh i Litera. 13-14. 227-235 (in Ukranian).

UNESCO (1995, November 16). Deklaratsija printsipov terpimosti [Declaration of Principles on Tolerance].

Retrieved

from: https://unesdoc.unesco.org/ark:/48223/pf0000101803_rus.page=94 (in Russian).

Matienko, O. S. (2006). Vykhovannia tolerantnosti u starshoklasnykiv serednikh zahalnoosvitnikh litseiv Frantsii [Upbringing tolerance in senior pupils of secondary general education lycees at France] (Abstract of candidate's thesis, The Institute of Educational Problems of the Academy of Pedagogical Science of Ukraine). Kyiv (in Ukranian).

Audigier, F. (1991). Enseigner la société, transmettre des valeurs: la formation civique et l'éducation aux droits de l'homme : une mission ancienne, des problèmes permanents, un projet toujours actuel. [Teaching society, transmitting values: civic education and human rights education: an old mission, permanent problems, a project that is still current]. Revue française de pédagogie. 94. 37-48 (in French).

Collin, D. (2005). Valeurs et idéologies. [Values and ideologies]. Retrieved from http://deniscollin.viabloga.com/news/valeurs-et-ideologies (in French).

Détrie, C. \& Lauriol, C. (2014). L'idéologie des Lumières. [The Enlightenment ideology]. Dire la tolérance. 49-53 (in French).

Hammoud, G. (2015). Éducation à la tolérance. [Education to tolerance]. Empan. 98. 122-125 (in French).

Mc Andrew, M., Tessier, C. \& Bourgeault, G. (1997). L'éducation à la citoyenneté en milieu scolaire au Canada, aux Etats-Unis et en France: des orientations aux réalisations. [Citizenship Education in Schools in Canada, the United States and France: Directions to Achievements]. Révue francaise de pédagogie. 121. 57-77 (in French).

Ministère de l'éducation nationale, de l'enseignement sepérieur et de la recherche (2015, June 25). [Ministry of National Education, Teaching and Research]. Programme d'enseignement moral et civique. Retrieved from http://cache.media.education.gouv.fr/file/ MEN_SPE_6/66/2/2015_BO_SPE_6pdf_478662.pdf (in French).

Ministère de l'éducation nationale et de la jeunesse (2015, April 23). [Ministry of National Education and Youth]. Socle commun de connaissances, de compétences et de culture. 
Retrieved from

https://www.education.gouv.fr/pid25535/bulletin_officiel.html?cid_bo=87834 (in

French).

Інформація про автора:

Лисенко Наталя Григорівна

ORCID 0000-0002-5263-3681; аспірант кафедри історії педагогіки та

порівняльної педагогіки, Харківський національний педагогічний університет імені Г.С. Сковороди,

вул. Валентинівська, 2, 61000

e-mail: lysenkon@yahoo.com
Information about the author: Lysenko Natalya Hryhorivna ORSID: $\quad$ 0000-0002-5263-3681; PhD candidate of the Department of History of Pedagogy and Comparative Pedagogy, Ukraine, Kharkiv, Street Valentynivska, 2, H. S. Skovoroda Kharkiv National Pedagogical University, 61000

e-mail: lysenkon@yahoo.com

Цитуйте цю статтю як: Лисенко Н.Г. Виховання толерантності в учнів шкіл Франції у контексті моральної та громадянської освіти. Теорія та методика навчання та виховання. 2019. № 47. C. 50-62.

DOI: $10.34142 / 23128046.2019 .47 .05$

Дата надходження статті до редакції: 26.09.2019

Стаття прийнята до друку: 09.10.2019 